\title{
Market Response toward Accrual Earnings Management, Real Transactions, and Strategic Revenue Recognition - Earnings Management ${ }^{1}$
}

\author{
Windy Puspita Dewi ${ }^{1}$, Antonius Herusetya ${ }^{1^{*}}$ \\ Universitas Pelita Harapan \\ Building D-1 $1^{\text {st }}$ Floor, Jl. M.H. Thamrin Boulevard \\ Tangerang, 15811 Banten \\ * Penulis korespondensi; Email: antonius.herusetya@uph.edu
}

\begin{abstract}
This study investigates how the capital market response to a variety of earnings management tools i.e., accrual-based earnings management, real transaction activities, and strategic revenue recognition. We measure the market response to the information content of earnings by the earnings response coefficient (ERC). By using pooled-OLS regression from 748 firm-years data of public listed companies on the Indonesian Stock Exchange (IDX) in 2004-2009, we find some evidence of a negative association between earnings response coefficients and information content of earnings that contained earnings management. Our study find that real transactions earnings management in operating activities has negative association with earnings response coefficient, but we do not find any evidence from the other earnings management tools. The findings of this study imply that the market participants are able to capture a certain kind of earnings management behaviour that may reduce the earnings response coefficient.
\end{abstract}

Keywords: Real transaction activities; accrual earnings management; strategic revenue recognition

\begin{abstract}
ABSTRAK
Penelitian ini bertujuan untuk mengetahui bagaimana respon pasar terhadap berbagai cara dalam melakukan manajemen laba seperti manajemen laba berbasis akrual, manajemen laba melalui aktivitas riil dan manajemen laba melalui strategi pengakuan pendapatan. Respon pasar terhadap kandungan informasi laba diukur dengan earning response coefficient (ERC). Data diolah menggunakan pooled-OLS untuk 748 pengamatan yang berasal dari perusahaan-perusahaan yang terdaftar di Bursa Efek Indonesia (BEI) selama perioe 2004-2009. Hasil pengujian menunjukkan adanya hubungan negatif antara earning response coefficients dan kandungan informasi laba yang mengandung manajemen laba. Penelitian ini juga menemukan bahwa manajemen laba melalui transaksi riil atas aktivitas operasi memiliki hubungan negatif dengan earning response coefficient, namun tidak ditemukan bukti untuk manajemen laba dengan cara yang lain. Temuan penelitian ini mengindikasikan bahwa pelaku pasar mampu menangkap perilaku menajemen laba tertentu yang berkemungkinan menurunkan earning response coefficient.
\end{abstract}

Kata kunci: Aktivitas transaksi riil; pengeloaan laba akrual; strategi pengakuan pendapatan

\section{INTRODUCTION}

Previous studies documented various earnings management tools used by public companies to meet earnings targets (Graham, Harvey, and Rajgopal 2005; Cohen, Dye and Lys 2008; 2005; Lin, Radhakrishnan, and Su 2006). Further research found that public companies began to

\footnotetext{
1 This paper has been presented at The $5^{\text {th }}$ International Accounting Conference and $2^{\text {nd }}$ Accounting Students Research Forum (IACSF), Nov. 24, 2014, Depok, Faculty of Economics, University of Indonesia
} 
switch from accrual-based earnings management to real earnings management in order to avoid auditor's findings (e.g., Graham et al. 2005). They also found that these real activities, including strategic revenue recognition in the form of accrued revenue and deferred revenue are used as a substitute for the accrual earnings management to meet earnings targets (Graham et al. 2005; Caylor 2010; Burnett, Cripe, Martin, and McAllister 2012).

Earnings management can reduce earnings quality and thus negatively impact the investor decision-making (Levitt 1998). The increasing earnings management behavior over time on the other hand will also gave impact to the decreasing of earnings information content measured by earnings response coefficients (ERC) (Dechow and Schrand 2004; Defond and Park 2001; Kothari 2001; Cohen et al. 2005).

If the market suspects earnings management in the reported earnings of public companies, ERC will be lower. Empirical studies support of the negative association between earnings management and the response of the market to earnings (Cohen et al. 2005; Lin and Shih 2006). Lin and Shih (2006) for example found that ERC for such firms that contain earnings management to achieve the earnings target is lower compared to a control group.

Our research is motivated with the problem whether investors in the Indonesian Capital Market (IDX) can detect various tools of earnings management, such as real earnings management in operating activities and strategic revenue recognition. Previous studies on earnings management in Indonesia were mostly done using the tradetional concept of earnings management, i.e., accrual-based earnings management while currently real earnings management has been used in business practices (e.g., Challen and Siregar 2011; Ratmono 2010; Herusetya 2012; Pujilestari and Herusetya 2013). This study investigates the association of various tools of earnings management used by the public companies in the Indonesia Stock Exchange with the market's reaction measured by the ERC. Specifically, this study examines the possibility of a negative association of accrual earnings management and real transacttions, both in operational activities and strategic revenue recognition ${ }^{2}$ to the ERC.

Further discussions in this study are as follows: Section II discusses literature review and hypotheses development. Section III discusses the research methodology. Section IV discusses the

\footnotetext{
2 Caylor (2010) uses the term strategic revenue recognition as one of the tools in real earnings management activities.
}

findings of the test, and Section V is the conclusions, implications and suggestions for further research.

\section{Information Content of Earnings and Earnings Response Coefficients}

Earnings provide information to investors. And previous studies have tested the association between stock returns and earnings at least since the publication of Ball and Brown (1968). Previous research provides a variety of approaches to test the market's reaction to the information content of earnings, among others using the earnings response coefficient/ERC (Dechow and Schrand 2004). Investors can determine whether the information content of earnings has value relevance or not using the ERC, because "ERC captures the marginal effect of a dollar of earnings on the price" (Ronen and Yaari 2008).

\section{Accrual Earnings Management and Earnings Response Coefficient}

Many companies have taken advantage of the flexibility in accounting policies that are allowed in the standard of reporting by doing earnings management using accruals for the purpose of reporting earnings (Healy and Wahlen 1999, Fields, Lys, and Vincent 2001). Accruals give an opportunity for managers to manage earnings, because managers need forecasts, estimates, and judgments ${ }^{3}$ (Dechow and Schrand 2004). The greater the level of discretion in accruals, the greater the opportunity for managers to manage earnings (Dechow, Sloan, and Sweeney 1995; Richardson, Sloan, Soliman, and Tuna 2003). Such earnings manipulations through the high discretionary accruals were found by Healy (1985) and Jones (1991). The existence of this earnings management will then reduce the earnings quality, and could reduce the investors' confidence in reported earnings (Levitt 1998; Frankel, Johnson, and Nelson 2002).

Earnings response coefficient measures how much investors react to the information content of earnings conveyed through the earnings surprise. Previous studies have found that earnings management as an indication of lower earnings quality can be detected by the market through the ERC. Imhoff (1992) found that companies with a higher ranking position in a particular industry have a higher ERC (Dechow and Schrand 2004). Dechow and Park (2001) concluded that investors assume that higher accrual rate is an indication of lower

\footnotetext{
3 For example, managers can determine for themselves how much allowance for doubtful accounts, product warranty costs, allowance for inventory obsolescence, and so on.
} 
earnings quality, and hence the investors give a lower response to earnings. Elliot and Hanna (1996) found lower ERC for each dollar of quarterly core earnings for the companies that record large, unusual and non-recurring charges compared to the companies that do not record the charges. With the above arguments, it is suspected there is a negative association between accrual earnings management and ERC, and thus our hypothesis is:

H1: Reported earnings that contains accrual earnings management has a negative association with earnings response coefficient.

\section{Real Earnings Management in Operating Activities and Earnings Response Coefficient}

Previous studies documented other tools of earnings management such as real earnings management (Graham et al. 2005; Roychowdhury 2006; Herusetya 2012, Burnett et al. 2012). Cohen et al. (2008) found that after the passage of the SOX Act in the United States, the trend of real transactionbased earnings management is increasing, while accrual-based earnings management is decreasing. This is because in auditing financial statements, external auditors are more difficult to detect real transactions compared to accrual-based earnings management (Burnett et al. 2012; Graham et al. 2005). In addition, managers have limited flexibility in accruals manipulation if accruals have been done in the previous years (Barton and Simko 2002). Real earnings management behavior had also been found in Indonesia (Herusetya 2012; Challen and Siregar 2011; Ratmono 2010).

Past research has documented that real earnings management in operating activities can be done in the form of doing excessive production, increasing sales by giving discounts and relaxing the credit requirements, delaying the operating expenses, as well as the combination of all of them (Cohen and Zarowin 2010; Roychowdhury 2006). If accrual earnings management reduces earnings quality, the real earnings management in the operating activities will also reduce the earnings quality, and is predicted to have a negative association with earnings response coefficient too. Based on the above arguments, our hypothesis to be tested is:

H2: Reported earnings that contains real earnings management in operating activities has a negative association with earnings response coefficient.

\section{Strategic Revenue Recognition and Earnings Response Coefficient}

The structure and the change over time of the real activities can be done through the strategic revenue recognition in accrued revenue and deferred revenue, as found by Caylor (2010). Caylor (2010) found that managers manipulate deferred revenue and accounts receivable to avoid negative earnings surprises, but found little evidence of managers to avoid losses or earning decreases. He found that managers perform manipulation of gross accounts receivable by providing an attracttive credit policy, easier credit eligibility requirements, as well as speeding delivery of goods. In addition, managers also perform earnings management in deferred revenue using manipulation in accounting estimates through changes in contractual agreements with customers in order to accelerate the recognition of receivables.

There is no previous study that examines the market's reaction to the information content of earnings, if the financial statements contain earnings management in strategic revenue recognition. Because of this strategic revenue recognition is one of the tools that managers could used, we expect that market has the ability to detect this kind of earnings management which is reflected in the reduced earnings response coefficient. Based on the above arguments, our hypothesis to be tested is:

H3: Reported earnings that contains real earnings management in strategic revenue recognition has a negative association with earnings response coefficients

\section{RESEARCH METHOD}

\section{Data and Sample Selection}

Financial data is extracted from the financial statements of non-financial public listed companies in the Indonesia Stock Exchange (IDX) from 20042009. The method of sample selection is purposive. We also exclude firms that are merging, listing and delisting throughout the observation period. Based on the selection criteria of the samples, we have 156 same companies in each year during the period 2004-2009 or 936 firm-years of observation 4 . However, after deducting the outliers with the amount of 189 firm-years data, we finally have 748 firm-years data as a sample. The description of sample selection can be seen in Table 1 .

\footnotetext{
4 Most of the research sample includes manufacturing firms (basic and industrial chemicals, industrial consumer goods, and miscellaneous industry) amounted to $58.33 \%$ of the existing number of samples, followed by trading companies, services and investments amounted to $29.49 \%$, and the rest is property and real estate industry for $12.18 \%$.
} 
Table 1. Empirical Test Result of Hypothesis 1

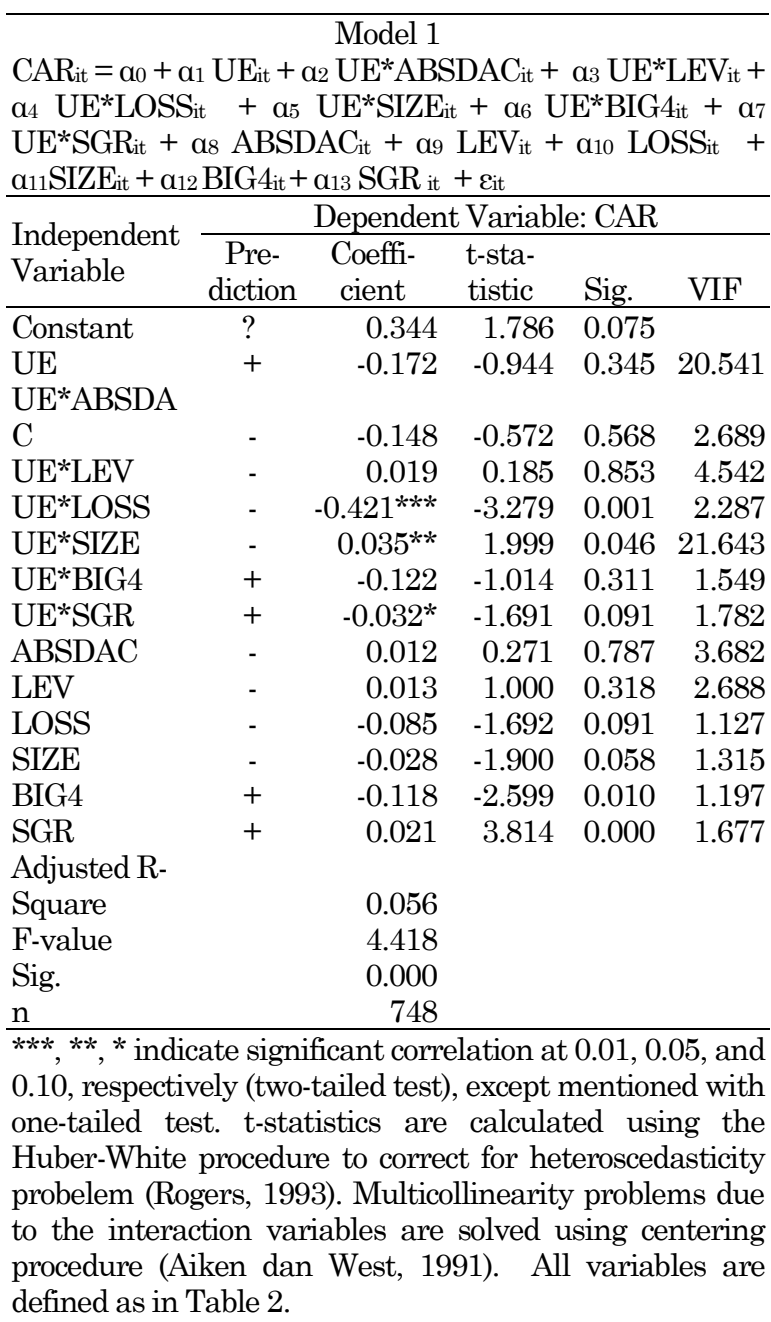

\section{Empirical Model}

\section{Accrual Earnings Management and Ear- nings Response Coefficient}

This study develops a cumulative abnormal return (CAR) model used by Ghosh and Moon (2005), and Herusetya (2012). Our empirical model to test the hypothesis $\mathrm{H} 1$ is as follows:

$\mathrm{CAR}_{\mathrm{it}}=\mathrm{\alpha}_{0}+\alpha_{1} \mathrm{UE}_{\mathrm{it}}+\alpha_{2} \mathrm{UE}^{*} \mathrm{ABSDAC}_{\mathrm{it}}+\mathrm{\alpha}_{3} \mathrm{UE}^{*}$ $\mathrm{LEV}_{\text {it }}+\alpha_{4} \mathrm{UE}^{*} \mathrm{LOSS}_{\mathrm{it}}+\mathrm{\alpha}_{5} \mathrm{UE}^{*} \mathrm{SIZE}_{\mathrm{it}}+$ $\alpha_{6} \mathrm{UE}^{*} \mathrm{BIG} 4_{\mathrm{it}}+\mathrm{a}_{7} \mathrm{UE} * \mathrm{SGR}_{\mathrm{it}}+\mathrm{a}_{8} \mathrm{ABSDAC}_{\mathrm{it}}$ $+\alpha_{9} \mathrm{LEV}_{\mathrm{it}}+\mathrm{\alpha}_{10} \mathrm{LOSS}_{\mathrm{it}}+\mathrm{\alpha}_{11} \mathrm{SIZE}_{\mathrm{it}}+$

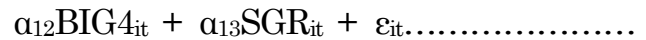
(Model 1)

In Model 1, our main variable of concern is UE*ABSDAC. The association between accrual earnings management and earnings response coefficient (ERC) is predicted negative and significant, i.e. coefficient of $\alpha 2$. This implies that the market react negatively to the accrual earnings management measured by the discretionary accrual.
Table 2. Variabel Descriptions

\begin{tabular}{|c|c|}
\hline \multicolumn{2}{|c|}{ Model 1- 3, and Equation (7): } \\
\hline CAR & $\begin{array}{l}=\text { Cumulative abnormal return of firm i for } \\
12 \text { months period, ending in } 3 \text { months of } \\
\text { the end of fiscal year }\end{array}$ \\
\hline \multirow[t]{2}{*}{$\mathrm{UE}$} & $\begin{aligned}= & \text { Unexpected earnings, calculated by the } \\
& \text { formula: } \mathrm{UE}_{\mathrm{it}}=\frac{\mathrm{EPS}_{\mathrm{it}}-\mathrm{EPS}_{\mathrm{it}-1}}{\mathrm{P}_{\mathrm{it}-1}}\end{aligned}$ \\
\hline & $\begin{array}{l}\text { Where: EPS is earnings per share, and } \mathrm{P} \\
\text { is price of the company's stock }\end{array}$ \\
\hline ABSDAC & $\begin{aligned}= & \text { Absolute discretionary accruals deflated } \\
& \text { by lag total assets, computed using } \\
& \text { Kothari et al. (2005) model }\end{aligned}$ \\
\hline REM & $\begin{aligned}= & \text { Real earnings management at agregate } \\
& \text { level, computed using Cohen et al. (2008) } \\
& \text { and Roychowdhury (2006). }\end{aligned}$ \\
\hline SSRN & $\begin{aligned} &= \text { Real earnings management in strategic } \\
& \text { revenue recognition computed using } \\
& \text { Caylor (2010) model. }\end{aligned}$ \\
\hline \multicolumn{2}{|r|}{ Control Variables - Model 1-3: } \\
\hline LEV & $\begin{aligned}= & \text { Leverage ratio, defined as total liabilities } \\
& \text { divided by total assets at the end year } t\end{aligned}$ \\
\hline LOSS & $\begin{aligned}= & \text { Dummy variable for loss firm, } 1 \text { if firm i } \\
& \text { at year t report net loss, } 0 \text { otherwise }\end{aligned}$ \\
\hline SIZE & $=$ Natural logarithm of total assets \\
\hline BIG4 & $\begin{aligned}= & \text { Dummy variable, } 1 \text { if the firm } i \text { is audited } \\
& \text { by Big } 4,0 \text { otherwise }\end{aligned}$ \\
\hline SGR & $\begin{aligned}= & \text { Sales } / \text { revenues growth, defined as (sales } \\
& \mathrm{t}-\text { sales } \mathrm{t}-1 \text { )/sales } \mathrm{t}-1\end{aligned}$ \\
\hline \multicolumn{2}{|r|}{ Equation $(1)-(6)$} \\
\hline TACC & $\begin{aligned} &= \text { Total accruals, defined as earnings before } \\
& \text { extraordinary items less cash flow from } \\
& \text { operation }\end{aligned}$ \\
\hline A & $=$ Total assets \\
\hline$\triangle \mathrm{REV}$ & $=$ Change in firm's net revenue in year $\mathrm{t}$ \\
\hline$\Delta \mathrm{AR}$ & $\begin{aligned}= & \text { Change in firm's account receivables in } \\
& \text { year t }\end{aligned}$ \\
\hline PPE & $=$ Property, plant and equipment \\
\hline ROA & $\begin{array}{l}=\text { Firm's return on assets, defined as the } \\
\text { ratio of net earnings deflated by total } \\
\text { assets }\end{array}$ \\
\hline $\mathrm{CFO}$ & $=$ Cash flow from operations \\
\hline Sales & $=$ Net sales \\
\hline$\Delta$ Sales & $=$ Change in firm's net sales in year t \\
\hline Prod & $\begin{aligned}= & \text { The sum of cost of goods sold and change } \\
& \text { in inventory in year t }\end{aligned}$ \\
\hline DisExp & $\begin{array}{l}=\text { The sum of Sales Expense, and General } \\
\text { and Administration Expense (SG \& A } \\
\text { expenses) }\end{array}$ \\
\hline$\Delta$ Gross AR & $=$ Change in gross account receivables \\
\hline$\Delta$ Def Rev & $\begin{aligned} &= \text { Change in deferred revenue in short term } \\
& \text { period }\end{aligned}$ \\
\hline$\Delta \mathrm{S}$ & $=$ Change in firm's net sales in year t \\
\hline$\Delta \mathrm{CFO}$ & $\begin{aligned}= & \text { Change in cash flow from operations } \\
& (\mathrm{CFO}) \text { in year } \mathrm{t}\end{aligned}$ \\
\hline & = Residual errors \\
\hline
\end{tabular}

Subscript i,t $=$ Identification for firm $\mathrm{i}$ and year $\mathrm{t}$

\section{Real Earnings Management in Operating} Activities and Earnings Response Coefficient

Empirical model that represent the testing of hypothesis $\mathrm{H} 2$ is as follows: 


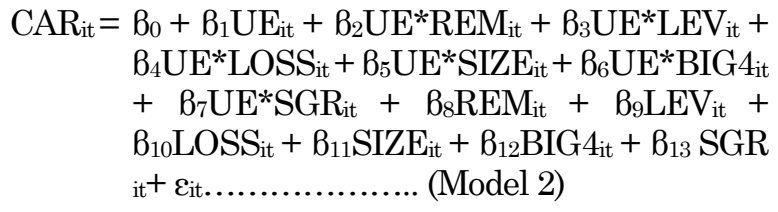

The main variable in Model 2 is UE*REM. Coefficient of $B 2$ is predicted negative and significant, which shows the negative association of real earnings management in operating activities and earnings response coefficients. This implies that the market react negatively to the real earnings management in operating activities at the aggregate level.

\section{Real Earnings Management in Strategic Revenue Recognition and Earnings Response Coefficient}

Empirical model that represent the testing of hypothesis H3 is as follows:

$\mathrm{CAR}_{\mathrm{it}}=\varphi_{0}+\varphi_{1} \mathrm{UE}_{\mathrm{it}}+\varphi_{2} \mathrm{UE}^{*} \mathrm{SRRN}_{\mathrm{it}}+\varphi_{3} \mathrm{UE}^{*} \mathrm{LEV}_{\mathrm{it}}$ $+\varphi_{4} \mathrm{UE}^{*} \mathrm{LOSS}_{\mathrm{it}}+\varphi_{5} \mathrm{UE}^{*} \mathrm{SIZE}_{\mathrm{it}}+\varphi_{6} \mathrm{UE}^{*}$ $\mathrm{BIG} 4_{i t}+\varphi_{7} \mathrm{UE}^{*} \mathrm{SGR}_{\mathrm{it}}+\varphi_{8} \mathrm{SRRN}_{\mathrm{it}}+\varphi_{9} \mathrm{LEV}_{\text {it }}$ $+\varphi_{10} \mathrm{LOSS}_{\mathrm{it}}+\varphi_{11} \mathrm{SIZE}_{\mathrm{it}}+\varphi_{12} \mathrm{BIG}_{\mathrm{it}}+\varphi_{13}$ $\mathrm{SGR}_{\text {it }}+\varepsilon_{\mathrm{it}} \ldots \ldots \ldots \ldots \ldots . . . . .($ Model 3$)$

The main variables in Model 3 is UE*SRRN. Coefficient of $\varphi 2$ is predicted negative and significant, which implies that the market react negatively to earnings management in strategic revenue recognition at the aggregate level, including the abnormal changes in accounts receivable and deferred revenue.

\section{Operationalization of Research Variables}

\section{Accrual Earnings Management (ABSDAC)}

This study uses the accrual model developed by Kothari, Leone, and Wasley (2005) to estimate the magnitude of discretionary accruals as follows: $\mathrm{TACC}_{\mathrm{it}} / \mathrm{A}_{\mathrm{it}-1}=\alpha_{0}+\alpha_{\mathrm{i}}\left[1 / \mathrm{A}_{\mathrm{it}-1}\right]+\mathrm{B}_{1 \mathrm{i}}\left[\Delta R E \mathrm{RV}_{\mathrm{it}}-\Delta \mathrm{AR} / \mathrm{A}_{\mathrm{it}-1}\right]$

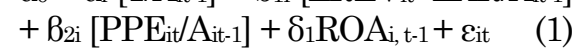

The variable definitions can be seen in Table 2. The value of discretionary accruals (DA) or abnormal discretionary residual error $(\varepsilon)^{5}$ of the regression equation (1), i.e., the difference of total accruals and fitted value of equation (1) is defined as DAit $=$ (TACCit)-NDAit. The absolute value of discretionnary accruals (ABSDAC) is used as a proxy of accrual earnings management, whether it is positive or negative throughout the period, because both signs are seen as a form of earnings management (Cohen et al. 2008).

\footnotetext{
5 The residual error for equation (1) is obtained from the OLS regression conducted cross-sectionally for each year in each industry using Stata sofware version 11.
}

\section{Real Earnings Management in Operating Activities (REM)}

This study uses model of real earnings management in operating activities applied by Roychowdhury (2006) and Cohen et al. (2008) to calculate the magnitude of real transactions at the individual level, i.e., abnormal operating cash flow (ABCFO), abnormal production costs (ABPROD), and abnormal discretionary expenses (ABDISEXP). To determine the normal level of variable operating cash flow (CFO), discretionary expenses, and production costs, we use model of Dechow, Kothari, and Watts (1998). We obtain the abnormal levels of each level using the difference between actual value of each variable and its fitted value from the OLS equation ${ }^{6}$.

To reflect the influence of real transactions at the aggregate level, we use REM variable because each variable has its implications for the different level of earnings. REM is the sum of the standardized values of ABCFO, ABPROD, and ABDISEXP $^{7}$. Real transaction earnings management is present if the sign of REM is positive (Cohen and Zarowin 2010).

\section{Abnormal Operating Cash Flow (ABCFO)}

Normal operating cash flow (CFO) is a linear function of sales and change in sales, and can be determined using the regression equation (2) as follows:
$\mathrm{CFO}_{\mathrm{it}} / \mathrm{A}_{\mathrm{it}-1}=\mathrm{k}_{\mathrm{it}}\left[1 / \mathrm{A}_{\mathrm{it}-1]}\right]+\mathrm{k}_{2}\left[\right.$ Sales $\left./ \mathrm{A}_{\mathrm{it}-1}-1\right]+\mathrm{k}_{3}[\Delta$ Salesit $\left./ A_{i t-1}\right]+\varepsilon_{i t}$

Variable definitions can be seen in Table 2 . Based on equation (2), we can calculate the abnormal operating cash flow (ABCFO), i.e., the difference between actual operating cash flow and its fitted value of the normal operating cash flow from the equation (2), or we can use the standard errors (e) of the regression equation (2) ${ }^{8}$.

\section{$\underline{\text { Abnormal Production Costs (ABPROD) }}$}

Cost of production is the sum of cost of goods sold and changes in inventory (Cohen et al. 2008),

\footnotetext{
${ }^{6}$ Each specification using OLS regression models conducted cross-sectionally for each year in each industry using Stata software version 11 .

7 Following Chi, Lisic, and Pevzner (2011), the standardized values for each variable in each year of observation can be calculated using the formula, for example $\mathrm{ABCFO}=$ (variable $\mathrm{ABCFO}$ - mean $\mathrm{ABCFO}$ )/standard deviation $\mathrm{ABCFO}$. Thus REM = - (standardized value of ABCFO) + (standardized value of ABPROD) - (value standardized of ABDISEXP).

${ }^{8}$ Regression was performed for each industry per each year to control the different characteristics in each industry with the minimum number of observations per industry is 15 companies (Gul, Fung, and Jaggi 2009; Roychowdhury 2006).
} 
so the estimated coefficients of normal level of production costs can be obtain using equation (3) as follows:

Prodit $/ A_{i t-1}=k_{1 t}\left[1 / A_{i t-1}\right]+\left[k_{2}\right.$ Salesit $\left./ A_{i t-1}\right]+k_{3}[\Delta$ Salesit

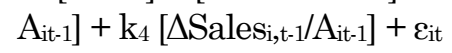

Based on the equation (3) we obtain the abnormal level of production costs (ABPROD), i.e., the difference between the actual production costs and its fitted value of the estimated coefficients from the equation (3).

\section{Abnormal Discretionary Operating Costs (ABDI- $\underline{\text { SEXP) }}$}

To find the normal level of discretionary expense (operating costs), we use the following equation:

DisExpit $/ A_{i t-1}=k_{1 t}\left[1 / A_{i t-1}\right]+\left[k_{2}\right.$ Sales $\left.i_{t,-1} / A_{i t-1}\right]+\varepsilon_{i t}$

The amount of abnormal discretionary operating costs (ABDISEXP) can be obtained from the actual value of discretionary operating costs minus fitted value of the estimated coefficient of the normal level of discretionary operating costs from equation (4).

\section{Strategic Revenue Recognition (SRRN)}

We use Caylor (2010) model to calculate the amount of strategic revenue recognition by identifying the abnormal changes in gross accounts receivable and deferred revenue. Because both magnitudes is a manipulation of revenue recognition and have implications to the earnings, and to reflect the overall strategic manipulation of revenue recognition, we use the aggregate level of variable (SRRN), i.e., + (SSRA standardized value) + (value SRRD standardized) $^{9}$. We suspect that managers conduct earnings management in strategic revenue recognition if the value of SSRN is positive.

\section{$\underline{\text { Abnormal Accruals Revenue Recognition (SSRA) }}$}

Following Caylor (2010), changes in abnormal gross accounts receivable (SRRA) is calculated as follows:

$\Delta$ Gross ARt $/ \mathrm{A}_{\mathrm{t}-1}=\mathrm{a}_{0}+\mathrm{a}_{1}\left(1 / \mathrm{A}_{\mathrm{t}-1}\right)+\mathrm{B}_{1}\left(\Delta \mathrm{S}_{\mathrm{t}} / \mathrm{A}_{\mathrm{t}-1}\right)+$

$$
B_{2}\left(\Delta \mathrm{CFO}_{\mathrm{t}}+{ }_{1} / \mathrm{A}_{\mathrm{t}-1}\right)+\varepsilon_{\mathrm{t}}
$$

SRRA is the difference between changes of actual gross accounts receivable and its predicted

\footnotetext{
Using the analogy of the aggregate value of real earnings management in operating activities, the standardized value of the SSRA and SSRD for each year can be calculated using the formula, for example, SSRA = (variable SSRA - mean SSRA)/standard deviation of SSRA.
}

normal value. Abnormal changes in gross trade receivables increased when the actual value is greater than the predicted value. Based on equation (5) we can calculate the abnormal changes in gross accounts receivable, i.e. the standard error (ع) of the regression equation (5). On the basis of these arguments, managers are suspected to conduct real earnings management in strategic revenue recognition when the standard error ( $(\varepsilon)$ is positive.

\section{Abnormal Deferred Revenue Recognition (SSRA)}

Following Caylor (2010), abnormal changes in deferred revenue (SRRD) can be calculated by the following regression equation:

$\Delta$ Def Revt $/ A_{t-1}=\alpha_{0}+a_{1}\left(1 / A_{t-1}\right)+B_{1}\left(\Delta S_{t+1} / A_{t-1}\right)+B_{2}(\Delta$

$$
\left.\mathrm{CFO}_{t} / \mathrm{A}_{\mathrm{t}-1}\right)+\varepsilon_{\mathrm{t}}
$$

Based on the equation (6) we can calculate SSRD value, i.e., the standard error $(\varepsilon)$ of regression equation (6). Abnormal changes in deferred revenue recognition occur when the actual change in the deferred revenue is greater than the estimated value. On the basis of these arguments, managers are suspected to conduct real earnings management in deferred strategic revenue recognition when the standard error $(\varepsilon)$ is positive (Pujilestari and Herusetya 2013).

\section{Earnings Response Coefficient (ERC)}

Following Hermawan (2009), the measurement of cumulative abnormal return (CAR) as a dependent variable is calculated using the cumulitive market adjusted returns. Abnormal return is the the excess of actual return from the normal return. Monthly abnormal return is calculated from the difference between the return of firm's shares $i$ and the market's return $m$, i.e. ARit $=$ Rit Rmt; whereas CAR is the sum of abnormal returns over the 12 months ending in three months after the end of the fiscal year. Here is the formula for obtaining the CAR:

$\mathrm{R}_{\mathrm{it}}=\frac{\mathrm{IHSI}_{\mathrm{it}}-\mathrm{IHSI}_{\mathrm{it}-1}}{\mathrm{IHSI}_{\mathrm{it}-1}} \quad \mathrm{R}_{\mathrm{mt}}=\frac{\mathrm{IHSG}_{\mathrm{it}}-\mathrm{IHSG}_{\mathrm{it}-1}}{\mathrm{IHSG}_{\mathrm{it}-1}}$

Where: IHSI = individual stock price index, and $\mathrm{IHSG}=$ composite stock price index .

While the earnings response coefficient is calculated using the following equation:

$\mathrm{CAR}_{\mathrm{it}}=\mathrm{a}+\delta \mathrm{UE}_{\mathrm{it}}+\varepsilon_{\mathrm{it}}$

UE variable is a variable to capture the earnings surprise measured with random walk model, i.e., Earnings per Share (EPS) in the current year minus previous year EPS (Herusetya 2012; Hermawan 2009). The coefficient $\delta$ is the earnings response coefficient (ERC). 


\section{Control Variables}

This study uses control variables in Model 1-3: (i) leverage (LEV); (ii) loss (LOSS); (iii) firm size (SIZE); (iv) Big 4 Firm (BIG4); and (v) sales growth (SGR).

SGR coefficient is predicted positive, because companies with high growth rates have higher ERCs than firms with lower growth rates (Scott 2009). The coefficient of LEV and LOSS, each of it is predicted negative, as firms with higher debt levels and experiencing loss has a lower ERC (Scott 2009; Dechow and Schrand 2004). SIZE is predictted negative because larger companies have more information than smaller companies, so the market's reaction becomes smaller. Audit quality of Big 4 is considered to have higher earnings quality than non-Big 4, so that BIG4 coefficient is predictted positive (Balsam et al. 2003). Based on the above arguments, the coefficient interaction of UE*SGR, UE*BIG4 are predicted positive and significant, while the coefficient of UE*LOSS, $\mathrm{UE}^{*} \mathrm{LEV}$, and $\mathrm{UE}^{*} \mathrm{SIZE}$ are predicted negative and significant.

\section{RESULTS AND DISCUSSIONS}

\section{Descriptive Statistics and Correlations}

The results of descriptive statistics and correlations of each variable in Model 1-3 after the process of winsorization are presented in Tables 3 and $4^{10}$. Mean of CAR of Model 1-3 (Table 3, Panel $\mathrm{A}, \mathrm{B}$, and C) are ranged from negative -0.077 to 0.079 , which indicates that the sample companies on average have negative abnormal return during the observation period 2004-2009. The mean of unexpected earnings (UE) is 0.010 and positive for all models, indicating that the sample firms on average reported an increase in earnings compared with the previous year. The mean of absolute discretionary accruals (ABSDAC) is 0.176 and positive (Table 3, Panel A), which indicates that the sample companies perform accrual earnings management by $17 \%$ of the total assets. The mean of real transaction earnings management at the

\footnotetext{
10 In order to avoid data that are outliers, we use winzorization procedures with 3 standard deviations of the mean for all continuous variables for each model (Acock 2008). Our classical assumption tests are made prior to the test of hypotheses which includes the test of data normality, multicollinearity test, and heteroscedasticity. Test of normality used the KolmogorovSminrnov test, the multicollinearity test used with the criteria of Variance Inflation Factor (VIF), and the heteroscedasticity tests used the White-heteroscedasticity method. To overcome the problems of multicollinearity, we use centering method for all continuous variables, i.e., the variable (x) - the mean of the variable (x) (Aiken and West 1991 in Kohler and Kreuter 2009).
}

aggregate level (REM) is 0.045 , indicating that the magnitude of real transaction in operating is $4.50 \%$ of total assets, while the mean of earnings management in strategic revenue recognition (SSRN) is 0.056 and negative, indicating that on average the public companies is reducing the magnitude of real transaction in revenue recognition, i.e., $-5.60 \%$ of total assets.

Table 3. Descriptive Statistics - Model 1-3

\begin{tabular}{|c|c|c|c|c|c|}
\hline \multicolumn{6}{|c|}{ Panel A. Model (n=748) } \\
\hline Main Variable & Mean & $\begin{array}{l}\text { Me- } \\
\text { dian }\end{array}$ & $\begin{array}{l}\text { Maxi- } \\
\text { mum }\end{array}$ & $\begin{array}{l}\text { Mini- } \\
\text { mum }\end{array}$ & $\begin{array}{l}\text { Std. } \\
\text { Devia- } \\
\text { tion }\end{array}$ \\
\hline CAR & -0.077 & -0.227 & -1.838 & 1.835 & 0.578 \\
\hline UE & 0.010 & 0.004 & 2.402 & -2.364 & 0.510 \\
\hline $\mathrm{UE}^{*} \mathrm{ABSDAC}$ & -0.004 & 0.001 & 0.852 & -1.251 & 0.130 \\
\hline ABSDAC & 0.176 & 0.085 & 18.463 & 0.000 & 0.868 \\
\hline \multicolumn{6}{|c|}{ Panel B. Model 2 (n=748) } \\
\hline CAR & -0.079 & -0.130 & 1.835 & -1.838 & 0.575 \\
\hline UE & 0.010 & 0.004 & 2.402 & -2.364 & 0.510 \\
\hline $\mathrm{UE}^{*} \mathrm{REM}$ & -0.006 & 0.000 & 3.499 & -3.552 & 0.284 \\
\hline REM & 0.045 & -0.031 & 34.824 & -34.613 & 2.395 \\
\hline \multicolumn{6}{|c|}{ Panel C. Model 3 (n=748) } \\
\hline CAR & -0.077 & -0.129 & 1.835 & -1.838 & 0.578 \\
\hline UE & 0.010 & 0.004 & 2.402 & -2.364 & 0.510 \\
\hline $\mathrm{UE}^{*} \mathrm{SRRN}$ & -0.001 & 0.002 & 0.275 & -0.268 & 0.062 \\
\hline SRRN & -0.056 & -0.097 & 0.589 & -0.689 & 0.187 \\
\hline \multicolumn{6}{|c|}{ Panel D. Control Variable - Model 1-3 } \\
\hline LEV & 0.613 & 0.543 & 8.575 & 0.000 & 0.561 \\
\hline LOSS & 0.250 & 0.000 & 1.000 & 0.000 & 0.433 \\
\hline SIZE & 13.409 & 13.262 & 18.223 & 8.520 & 1.619 \\
\hline $\mathrm{BIG} 4$ & 0.430 & 0.000 & 1.000 & 0.000 & 0.495 \\
\hline SGR & 0.639 & 0.151 & 66.163 & -2.418 & 4.791 \\
\hline
\end{tabular}

All variables are defined as in Table 2 . Winzorization procedures are done using 3 deviation standards from the mean for all continuous data to avoid data outliers.

Correlations among the operasional variables of Model 1-3 are presented in Table 4. ABSDAC in Model 1 (Table 4, Panel A) is negatively correlated with the UE at 0.05 , implying that accrual earnings management has negative impact to the market's reaction as shown by negative earnings response coefficients, consistent with our initial prediction. REM in Model 2 (Panel B) and SSRN in Model 3 (Panel C), each of which is not correlated with UE, despite each one has a negative sign. Some of the control variables in the models have negative and significant correlations with UE. UE consistently have a negative correlation to LOSS for each model (Panel A, B, C) at 0.01, consistent with the previous studies (Balsam, Krishnan, and Yang 2003; Scott 2009; Dechow and Schrand 2004). LEV has a negative correlation with UE at 0.01 for Models 2 and 3 (Panels B, C), but has no correlation with UE for Model 1 (Panel A). This correlation implies that the companies with high degree of leverage and reported loss would result to a negative earnings surprise (Scott 2009; Balsam et al. 2003). UE has no correlation to the other control variables such as SIZE, BIG4, and SGR for all models (Panels A, B, C). 


\section{Empirical Test of Hypothesis 1}

Testing result of Hypothesis 1 using Model 1 (Table 5) has adjusted R-Square of 5.6\% and Fvalue of 4.418 at $0.01(\mathrm{p}=0.000)$. Coefficient $\mathrm{a} 2$ (UE*ABSDAC) has a value of -0.148 , but not significant at $0.10(\mathrm{t}=-0.572)$. Thus we do not find evidence that the accrual earnings management gives a negative impact to the market as shown from the insignificant of the UE*ABSDAC coefficients. This implies that the capital market participants cannot capture any accrual earnings management undertaken by the company. Thus, hypothesis $\mathrm{H} 1$ is rejected.

Table 5. Empirical Test Result of Hypothesis 1

\begin{tabular}{|c|c|c|c|c|c|}
\hline \multirow{2}{*}{\multicolumn{6}{|c|}{ 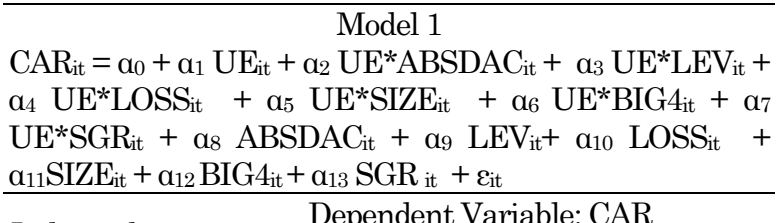 }} \\
\hline & & & & & \\
\hline $\begin{array}{c}\text { Independent } \\
\text { Variable }\end{array}$ & $\begin{array}{l}\text { Predic- } \\
\text { tion }\end{array}$ & $\begin{array}{c}\text { Coeffi- } \\
\text { cient }\end{array}$ & $\begin{array}{l}\text { t-sta- } \\
\text { tistic }\end{array}$ & Sig. & VIF \\
\hline Constant & $?$ & 0.344 & 1.786 & 0.075 & \\
\hline UE & + & -0.172 & -0.9 & 0.345 & 20.541 \\
\hline UE*ABSDAC & - & -0.148 & -0.57 & 0.568 & \\
\hline UE*LEV & - & 0.019 & 0.185 & 0.853 & \\
\hline UE*LOSS & - & $-0.421^{* * *}$ & -3.27 & 0.001 & 2.28 \\
\hline UE*SIZE & - & $0.035^{* *}$ & 1.999 & 0.046 & 21.64 \\
\hline $\mathrm{UE}^{*} \mathrm{BIG} 4$ & + & -0.122 & -1.014 & 0.311 & \\
\hline $\mathrm{UE}^{*} \mathrm{SGR}$ & + & $-0.032^{*}$ & -1.691 & 0.091 & \\
\hline ABSDAC & - & 0.012 & 0.271 & 0.787 & \\
\hline LEV & - & 0.013 & 1.00 & 0.318 & 2.68 \\
\hline LOSS & - & -0.085 & -1.69 & 0.091 & 1.12 \\
\hline SIZE & - & -0.028 & -1.9 & 0.0 & \\
\hline BIG4 & + & -0.118 & -2.5 & 0.010 & 1.197 \\
\hline SGR & + & 0.021 & 3.814 & 0.000 & 1.677 \\
\hline \multicolumn{6}{|l|}{ Adjusted R- } \\
\hline Square & & 0.056 & & & \\
\hline F-value & & 4.418 & & & \\
\hline Sig. & & 0.000 & & & \\
\hline $\mathrm{n}$ & & 748 & & & \\
\hline
\end{tabular}

$* * *, * *, *$ indicate significant correlation at $0.01,0.05$, and 0.10 , respectively (two-tailed test), except mentioned with one-tailed test. t-statistics are calculated using the HuberWhite procedure to correct for heteroscedasticity probelem (Rogers, 1993). Multicollinearity problems due to the interaction variables are solved using centering procedure (Aiken dan West, 1991). All variables are defined as in Table 2.

The testing results of control variables UE*LOSS ( $\alpha 4=-0.421, \mathrm{t}=-3.279)$ is negative and significant at 0.01 (Table 5), which imply that the companies with reported net loss will give a negative earnings surprise (Scott, 2009; Balsam et al., 2003). Variable UE*SIZE ( $\left.\mathrm{U}^{*}=0.035, \mathrm{t}=1.999\right)$ is positive and significant at 0.05 , in contrast with the previous studies (e.g. Balsam et al. 2003).
Variable $\mathrm{UE}^{*} \mathrm{SGR}(\alpha 7=-0.032, \mathrm{t}=-1.691)$ is negative and significant at 0.10 , contrast with the previous results (e.g., Balsam et al. 2003; Scott 2009). While other control variables such as UE*LEV and $\mathrm{UE}^{*} \mathrm{BIG} 4$ have no correlation on ERC.

\section{Empirical Test of Hypothesis 2}

The result of Hypothesis 2 testing using Model 2 (Table 6) has adjusted R-square of $6.2 \%$ and F-value of 4,799 significant at $0.01(p=0.000)$. The results of this study indicate that $\alpha 2$ has a value of $-0.111(t=-1.526)$, not significant at 0.10 with a two-tailed test, but significant in one-tailed test (critical value t-test $=1.28$ ) at 0.10 . This implies that market participants can capture the real earnings management at the aggregate level which gives a negative impact on the information content of earnings or gives result to a lower ERC.Thus the hypothesis H2 is accepted.

Table 6. Empirical Test Result of Hypothesis 2

\begin{tabular}{|c|c|c|c|c|c|}
\hline \multicolumn{6}{|c|}{$\begin{array}{l}\text { Model } 2 \\
\mathrm{CAR}_{\mathrm{it}}=\beta_{0}+\beta_{1} \mathrm{UE}_{\mathrm{it}}+\beta_{2} \mathrm{UE}^{*} \mathrm{REM}_{\mathrm{it}}+\beta_{3} \mathrm{UE}^{*} \mathrm{LEV}_{\mathrm{it}}+\beta_{4} \\
\mathrm{UE}^{*} \mathrm{LOSS}_{\mathrm{it}}+\beta_{5} \mathrm{UE}^{*} \mathrm{SIZE}_{\mathrm{it}}+\beta_{6} \mathrm{UE}^{*} \mathrm{BIG}_{\mathrm{it}}+\beta_{7} \\
\mathrm{UE}^{*} \mathrm{SGR}_{\mathrm{it}}+\beta_{8} \mathrm{REM}_{\mathrm{it}}+\beta_{9} \mathrm{LEV}_{\mathrm{it}}+\beta_{10} \mathrm{LOSS}_{\mathrm{it}}+B_{11} \mathrm{SIZE}_{\mathrm{it}} \\
+\beta_{12} \mathrm{BIG}_{\mathrm{it}}+\beta_{13} \mathrm{SGR}_{\mathrm{it}}+\varepsilon_{\mathrm{it}}\end{array}$} \\
\hline \multirow{2}{*}{$\begin{array}{l}\text { Inde- } \\
\text { pendent } \\
\text { Variable } \\
\end{array}$} & \multicolumn{5}{|c|}{ Dependent Variable: CAR } \\
\hline & $\begin{array}{c}\text { Predic- } \\
\text { tion }\end{array}$ & $\begin{array}{c}\text { Coeffi- } \\
\text { cient }\end{array}$ & $\begin{array}{l}\text { t-sta- } \\
\text { tistic }\end{array}$ & Sig & VIF \\
\hline Constant & $?$ & 0.374 & 1.961 & 0.05 & \\
\hline UE & + & -0.181 & -1.023 & 0.307 & 19.664 \\
\hline $\mathrm{UE}^{*} \mathrm{REM}$ & - & $-0.111^{*}$ & -1.526 & 0.127 & 1.026 \\
\hline UE*LEV & - & -0.044 & -0.441 & 0.659 & 4.127 \\
\hline UE*LOSS & - & $-0.410^{* * *}$ & -3.254 & 0.001 & 2.236 \\
\hline UE*SIZE & - & $0.039 * *$ & 2.199 & 0.028 & 21.642 \\
\hline $\mathrm{UE}^{*} \mathrm{BIG} 4$ & + & $-0.172^{*}$ & -1.433 & 0.152 & 1.575 \\
\hline UE*SGR & + & $-0.029 *$ & -1.571 & 0.117 & 1.775 \\
\hline REM & - & $-0.024^{* * *}$ & -2.755 & 0.006 & 1.014 \\
\hline LEV & - & 0.036 & 0.885 & 0.376 & 1.257 \\
\hline LOSS & - & -0.084 & -1.639 & 0.102 & 1.189 \\
\hline SIZE & - & -0.031 & -2.166 & 0.031 & 1.279 \\
\hline BIG4 & + & -0.117 & -2.580 & 0.010 & 1.206 \\
\hline SGR & + & 0.020 & 3.694 & 0.000 & 1.672 \\
\hline \multicolumn{6}{|l|}{ Adjusted } \\
\hline R-Square & & 0.062 & & & \\
\hline F-value & & 4.799 & & & \\
\hline Sig. & & 0.000 & & & \\
\hline $\mathrm{n}$ & & 748 & & & \\
\hline
\end{tabular}

$* * * * * *, *$ indicate significant correlation at $0.01,0.05$, and 0.10 , respectively (two-tailed test), except mentioned with one-tailed test. t-statistics are calculated using the Huber-White procedure to correct for heteroscedasticity probelem (Rogers, 1993). Multicollinearity problems due to the interaction variables are solved using centering procedure (Aiken dan West, 1991). All variables are defined as in Table 2.

The results of UE*LOSS testing as control variable (Table 6) find a negative and significant 
coefficient $(B 4=-0.410, \mathrm{t}=-3.254)$ at 0.01 , consistent with previous predictions. Other control variables, $\mathrm{EU} * \mathrm{SIZE}(B 5=0.039, \mathrm{t}=2.199)$ is positive at 0.05 contrast with predictions, $\mathrm{UE} * \mathrm{BIG} 4(66=-0.172, \mathrm{t}=-1.433)$, and $\mathrm{UE} * \mathrm{SGR}$ $(B 7=-0.029, \mathrm{t}=-1.571)$ is negative respectively at 0.10 with a one-tailed test (critical value t-test $=$ 1.28), different from the previous studies (Balsam et al. 2003; Scott 2009). While UE*LEV does not affect the ERC.

\section{Empirical Test of Hypothesis 3}

The result of Hypothesis 3 testing using Model 3 (Table 7) has adjusted R-square of $6.7 \%$ and F-value of 4.073, significant at $0.01(\mathrm{p}=0.000)$. The main coefficient of a $2\left(\mathrm{UE}^{*} \mathrm{SRRN}\right)$ has a value of $0.267(\mathrm{t}=0.611)$, not significant at 0.10 . The result of this test has not found evidence that strategic revenue recognition as an earnings management tools give a negative impact to the market. Thus, the hypothesis H3 is rejected. An alternative explanation to this could be that the public companies in Indonesia do not use strategic revenue recognition as an earnings management tool significantly, both in the recognition of accrued revenue and deferred revenue, so the market cannot capture this kind of earnings management behavior.

Table 7. Empirical Test Result of Hypothesis 3

\begin{tabular}{|c|c|c|c|c|c|}
\hline \multicolumn{6}{|c|}{$\begin{array}{l}\text { Model } 3 \\
\mathrm{CAR}_{\mathrm{it}}=\varphi_{0}+\varphi_{1} \mathrm{UE}_{\mathrm{it}}+\varphi_{2} \mathrm{UE}^{*} \mathrm{SRRN}_{\mathrm{it}}+\varphi_{3} \mathrm{UE}^{*} \mathrm{LEV}_{\mathrm{it}}+\varphi_{4} \\
\mathrm{UE}^{*} \mathrm{LOSS}_{\mathrm{it}}+\varphi_{5} \mathrm{UE}^{*} \mathrm{SIZE}_{\mathrm{it}}+\varphi_{6} \mathrm{UE}^{*} \mathrm{BIG}_{\mathrm{it}}+\varphi_{7} \\
\mathrm{UE}^{*} \mathrm{SGR}_{\mathrm{it}}+\varphi_{8} \mathrm{SRRN}_{\mathrm{it}}+\varphi_{9} \mathrm{LEV}_{\mathrm{it}}+\varphi_{10} \mathrm{LOSS}_{\mathrm{it}}+\varphi \mathrm{SIZE}_{11} \text { it } \\
+\varphi_{12} \mathrm{BIG}_{\mathrm{it}}+\varphi_{13} \mathrm{SGR}_{\mathrm{it}}+\varepsilon_{\mathrm{it}}\end{array}$} \\
\hline \multirow{2}{*}{$\begin{array}{l}\text { Inde- } \\
\text { pendent } \\
\text { Variable }\end{array}$} & \multicolumn{5}{|c|}{ Dependent Variable: CAR } \\
\hline & $\begin{array}{l}\text { Predic- } \\
\text { tion }\end{array}$ & $\begin{array}{c}\text { Coeffi- } \\
\text { cient }\end{array}$ & $\begin{array}{l}\text { t-sta- } \\
\text { tistic }\end{array}$ & Sig & VIF \\
\hline Constant & $?$ & 0.378 & 1.954 & 0.051 & \\
\hline UE & + & -0.161 & -0.871 & 0.384 & 20.971 \\
\hline UE*SRRN & - & 0.267 & 0.611 & 0.541 & 1.704 \\
\hline $\mathrm{UE}^{*} \mathrm{LEV}$ & - & -0.047 & -0.471 & 0.638 & 4.152 \\
\hline UE*LOSS & - & $-0.435^{* * *}$ & -3.392 & 0.001 & 2.263 \\
\hline UE*SIZE & - & $0.039^{* *}$ & 2.166 & 0.031 & 21.961 \\
\hline $\mathrm{UE}^{*} \mathrm{BIG} 4$ & + & -0.124 & -1.034 & 0.301 & 1.547 \\
\hline UE*SGR & + & $-0.029^{*}$ & -1.556 & 0.120 & 1.776 \\
\hline SRRN & - & -0.02 & -0.182 & 0.856 & 1.037 \\
\hline LEV & - & 0.032 & 0.777 & 0.438 & 1.255 \\
\hline LOSS & - & -0.085 & -1.633 & 0.103 & 1.192 \\
\hline SIZE & - & -0.031 & -2.141 & 0.033 & 1.281 \\
\hline BIG4 & + & -0.117 & -2.547 & 0.011 & 1.216 \\
\hline SGR & + & 0.020 & 3.662 & 0.000 & 1.680 \\
\hline \multicolumn{6}{|l|}{ Adjusted R- } \\
\hline & & 0.051 & & & \\
\hline F-value & & 4.073 & & & \\
\hline Sig. & & 0.000 & & & \\
\hline $\mathrm{n}$ & & 748 & & & \\
\hline
\end{tabular}

0.10, respectively (two-tailed test). t-statistics are calculated using the Huber-White procedure to correct for heteroscedasticity probelem (Rogers, 1993). Multicollinearity problems due to the interaction variables are solved using centering procedure (Aiken dan West, 1991). All variables are defined as in Table 2.

\section{CONCLUSIONS}

This study examines how the market response toward the various tool of opportunistic earnings management. Opportunistic earnings management is measured by accrual earnings management, real transactions in operating activities, and strategic revenue recognition. While the market's reaction to the information content of earnings is measured by earnings response coefficients (ERC). Our final sample consists of 748 firmyears observation from non-financial public listed companies in the Indonesia Stock Exchange (IDX) from the period of 2004-2009.

Using the pooled OLS regression, our study find evidence that real earnings management in operating activities has negative association with earnings response coefficients (ERC).This evidence implies that market react negatively toward the real earnings management. Our evidence gives also the interpretation that real earnings management in operating activities aredone at the aggregate level, which consist of the activities in accelerating sales transactions, performing excess production, and/or manipulating the discretionary operating expenses (Rowchowdhury 2006).

We do not find evidence that accrual earnings management and real transaction in strategic revenue recognition have negative impact to the market's response measured by earnings response coefficients (ERC). Several alternative explanations for this are the accruals management may have been detected by the auditor, so that it becomes less relevant to the market participants. In addition, the role of capital market regulation to improve compliance with the financial reporting standards make real earnings management more easily detected by the market.

Overall, this study find some evidence that the majority of the market participants in Indonesia can capture the earnings management tools used by the public companies reflected in the decreasing earnings response coefficients (ERC). This study has limitations among others, i.e. the accrual model used is still a controversy among the previous researchers, because there is still no consensus which model is more reliable in estimating discretionary accruals (Gul et al. 2009). Thus the result of this study is sensitive to the accrual models used. Previous studies have sugges- 
ted that the real transaction earnings management is not only limited to operating transactions, but can also be done in investing and financing activities, as well as other forms of activities (Xu, Taylor, and Dugan 2007; Burnett et al. 2012). Further studies are expected to examine the real transactions of investment and financing apart from the operational activities. Future studies are also expected to control the investors between sophisticated and not sophisticated investors.

\section{REFERENCES}

Acock, A. C. (2008). A Gentle Introduction to Stata, 2nd edition, A Stata Press Publication, Stata Corp LP, Texas.

Aiken, L. S. and West, S. G. (1991). Multiple Regression: Testing and Interpreting Interactions. Newbury Park, CA: Sage, dalam Kohler, U., and F. Kreuter. 2009. Data Analysis Using Stata. $2^{\text {nd }}$ Edition. Texas: A Stata Press Publication, Stata Corp LP.

Balsam, S., Krishnan, J., and Yang, J. S. (2003). Auditor Industry Specialization and Earnings Quality. Auditing: A Journal of Practice \& Theory, 22(2), 71-97.

Barton, J. and Simko, P. J. (2002). The Balance Sheet as an Earnings Management Constraint. The Accounting Review, 77, 1-27.

Burnett, M. B., Cripe, B. M., Martin, G. W., and Mc Allister, B. P. (2012). Audit Quality and the trade-off between Accretive Stock Repurchases and Accrual-Based Earnings Management. The Accounting Review, 87(6), 1861-1884.

Caylor, M. L. (2010). Strategic Revenue Recognition to Achieve Earnings Benchmarks. Journal of Accounting and Public Policy, 29, 82-95.

Challen, A. E. and Siregar, S. V. (2011). The Effect of Audit Quality on Earnings Management and Firm Value. Working paper.Presented at The 12th Asian Academic Accounting Association, October 8-12, 2011, Bali. Indonesia.

Chi, W., Lisic, L. L. and Pevzner, M. (2011). Is Enhanced Audit Quality Associated With Greater Real Earning Management? Accounting Horizon, 25(2), 315-335.

Cohen, D. A. and Zarowin, P. (2010). AccrualBased and Real Earning Management Activities around Seasoned Equity Offerings. Journal of Accounting and Economics, doi:10.1016/ j.jacceco.2010.01.002.

Cohen, D. A., Dey, A., and Lys, T. Z. (2008). Real and Accrual Based Earnings Management in the Pre- and Post- Sarbanes Oxley Periods. The Accounting Review, 83(3), 757-787.

Cohen, D. A., Dey, A., and Lys. T. Z. (2005). Trend in Earnings Management and Informativeness of Earnings Announcements in the Pre- and Post-Sarbanes Oxley Periods.Working paper, available at http://www.ssrn.com.

Dechow, P. M. and Schrand, M.C. (2004). Earnings Quality. The Research Foundation for CFA Institute, USA.

DeFond, M. L. and Park, C. W. (2001). The reversal of Abnormal Accruals and the Market Valuation of Earnings Surprises. The Accounting Review, 76(3), 375-404.

Dechow, P. M., Sloan, R.G., and Sweeney, A. P. (1995). Detecting Earnings Management. The Accounting Review, 70(2), 193-225.

Dechow, P. M., Kothari, S. P., and Watts, R. L. (1998). The Relation between Earnings and Cash Flows. Journal of Accounting and Economics 25: 133-168, dalam Roychowdhury, S. 2006. Earnings Management through Real Activities Manipulation.Journal of Accounting and Economics, 42(3), 335-370.

Elliot, J. A. and Hanna, J. D. (1996). Repeated Accounting Write-Offs and the Information Content of Earnings. Journal of Accounting Research, 34(Supplements), 135-155.

Fields, T. D., Lys, T. Z. and Vincent, L. (2001). Empirical Research on Accounting Choice. Journal of Accounting and Economics 31(1-3), 255307.

Frankel, R. M., Johnson, M. F., and Nelson, K. K. (2002). The Relation between Auditors's Fee for Non-audit Services and Earnings Management. The Accounting Review, 77, 71-105.

Ghosh, A. and Moon, D. (2005). Auditor Tenure and Perceptions of Audit Quality. The Accounting Review, 80(2), 585-612.

Graham, J. R., Harvey, C. R. and Rajgopal, S. (2005). The Economic Implications of Corporate Financial Reporting. Journal of Accounting and Economics, 40, 3-73.

Gujarati, D. N. (2003). Basic Econometrics. McGraw Hill, 3rd edition.

Gul, F. A., Fung, S. Y. K., and Jaggi, B. (2009). Earning Quality: Some Evidence on The Role of Auditor Tenure and Auditors's Industry Expertise.Journal of Accounting and Economics, 47, 265-287.

Healy, P. M. and Wahlen, J. M. (1999). A Review of The Earnings Management Literature and Its Implications For Standard Setters. Accounting Horizons, 13(4), 365-383.

Healy, P. (1985). The Effect of Bonus Schemes on Accounting Decisions. Journal of Accounting and Economics, 7, 85-107.

Hermawan, A. (2009). Pengaruh Efektifitas Dewan Komisaris dan Komite Audit, Kepemilikan Oleh Keluarga, dan Peran Monitoring Bank terhadap Kandungan Informasi Laba. Disertasi, Pascasarjana Ilmu Akuntansi, Fakultas Ekonomi Universitas Indonesia. 
Herusetya, A. (2012). Analisis Audit Quality Metric Score (AQMS) Sebagai Pengukur Multidimensi Kualitas Audit Terhadap Manajemen Laba dan Kandungan Informasi Laba.Disertasi, Pascasarjana Ilmu Akuntansi, Fakultas Ekonomi Universitas Indonesia.

Hung, M. (2000). Accounting Standards and Value Relevance of Financial Statements: An International Analysis. Journal of Accounting and Economics, 30(3), 401-420.

Imhoff, E. A. (1992). The Relation between Perceived Accounting Quality and Economic Characteristics of the Firm. Journal of Accounting and Public Policy, 11, 2, 97-118 in Dechow, P. M. and M. C. Schrand. 2004. Earnings Quality. The Research Foundation for CFA Institute, USA.

Jones, J. J. (1991). Earnings Management during Import Relief Investigations. Journal of Accounting Research, 29(2), 193-228.

Kim, O. and Verrecchia, R. (2001).The Relation among Disclosure, Returns, and Trading Volume Information. The Accounting Review, 76, 4, 633-654.

Kothari, S.P., Leone, A. J., and Wasley, C. E. (2005). Performance Matched Discretionary Accrual Measures. Journal of Accounting and Economics, 39, 163-197.

Kothari, S. P. (2001). Capital Market Research in Accounting. Journal of Accounting and Economics 31(1-3), 105-231.

Leuz, C., Nanda, D., and Wysocki (2003). Earnings Management and Investor protection: An International Comparison. Journal of Financial Economics, 69(3), 505-527.

Levitt, A. (1998). The Number Game. A Speech delivered at The NYU Center for Law of Business, New York. Available on http://www.sec.gov/spch220.txt.
Lin, S., Radhakrishnan, S., and Su, L.,N. (2006). Earnings Management and Guidance for Meeting or Beeting Analysts' Earnings Forcasts. Working paper. Available on SSRN.com/abstract $=928182$.

Lin, Z. X. and Shih, M. (2006). Does Market See a Zero or Small Positive Earnings Surprise as a Red Flag? Working paper. Available on SSRN.com/abstract $=929943$.

Pujilestari, R. dan Herusetya, A. (2013). Pengaruh Kualitas Audit terhadap Manajemen Laba Transaksi Real- Pengakuan Pendapatan Strategis. Jurnal Akuntansi dan Keuangan, 15(2), $75-85$.

Ratmono, D. (2010). Manajemen Laba Riil dan Berbasis Akrual: Dapatkah Auditor yang Berkualitas Mendeteksinya? Working paper. Disajikan pada SNA XIII, Universitas Jenderal Soedirman, Purwokerto.

Richardson, S. A., Sloan, R. G., Soliman, M. T., and Tuna, A. I. (2003). Information in Accruals about the Quality of Earnings. Working paper, University of Michigan.

Rogers, W.H. (1993). Regression Standard Errors in Clustered Samples. Stata Technical Bulletin 13, 19-23. Reprinted in Stata Technical Bulletin Reprints 3, 88-94.

Roychowdhury, S. (2006). Earnings Management through Real Activities Manipulation. Journal of Acconting and Economics, 42(3), 335-370.

Scott, W. R. (2009). Financial Accounting Theory. $5^{\text {th }}$ edition. Prentice Hall Inc. Canada, Ontario.

Xu, R. Z., Taylor, G.K., and Dugan, M. T. (2007). Review of Real Earnings Management Literature. Journal of Accounting Literature, 26, 195228.

Zang, A. Y. (2012). Evidence on The Trade off Between Real Activities Manipulation and Accrual-Based Earnings Management. The Accounting Review, 87(2), 675-703. 